\title{
Morphometric parameters of Phragmites australis as indicators of soil salinity: habitat and remote sensing approach as exemplified by brine-supplied salt marshes in the Parsęta Valley (NW Poland)
}

\author{
*Beata Bosiacka, *Pawel Pieńkowski, **Marek Podlasiński \\ *Department of Plant Taxonomy and Phytogeography, University of Szczecin, \\ Wąska 13, 71-415 Szczecin, Poland \\ e-mail: bebos@univ.szczecin.pl \\ **Department of Soil Erosion and Soil Reclamation, Agricultural University in Szczecin, \\ Papieża Pawła VI 3, 71-442 Szczecin, Poland
} Summary.The paper illustrates an application of morphometric parameters of common reed to locate saline patches in extensive
rush complexes. The study evaluated the applicability of aerial photographs and explored effects of soil salinity on reed stem mean
height $(\mathrm{r}=-0.72)$ and diameter $(\mathrm{r}=0.52)$.

Key words: inland salt marshes, aerial photos, common reed-environment relations.

\section{Introduction}

As salt marshes cease to be grazed upon and mown, they usually succumb to overgrowing by common reed, which makes it difficult to locate patches of halophilous vegetation capable of surviving among extensive rushes. The effect applies particularly to inland salt marshes supplied with brine from point sources. We present examples of halophilous vegetation patches discovered, using aerial photographs, among expanses of common reed. We explored factors determining different phototones and studied morphometric variability of the reed growing along the soil salinity gradient. The results will be used in a further search for halophilous vegetation patches among extensive reed complexes growing on salt structure-rich areas in NW Poland.

\section{Study area}

Salt marshes in the Parsęta Valley are located in the vicinity of the city of Kołobrzeg, $3 \mathrm{~km}$ away from the Baltic coast. The presence of brine in the area is associated with culmination part of the Middle Polish Anticlinorium (Kaczor 2005).

Halophilous vegetation patches (Salicornia europaea community Puccinellia distans-Spergularia marina comm., Juncus gerardi comm., Phragmites australisAtriplex hastata var. salina comm.) are dispersed within a 50 ha complex of high-rising, marshy reed rushes on the eastern bank of River Parsęta (Bosiacka et al. 2011). 


\section{Research methods}

Field surveys were conducted in early August 2010. A total of 45 soil samples from the root zone $(0-25 \mathrm{~cm})$ were collected along transects extending from brine seeps to margins of the brine-affected area. At each sampling site, five reed shoots were measured and examined. The presence or absence of the inflorescence was recorded; the shoot height and the stem diameter (at the first internode) were measured; the number of nodes was recorded. The measurements and counts were averaged.

The soil samples were analysed for the following parameters: moisture content (by weighing the samples before and after drying at $105^{\circ} \mathrm{C}$ ), organic matter content (loss on ignition), $\mathrm{pH}$ (potentiometry), and electrical conductivity of the saturated extracts (EC $_{\mathrm{e}}$ (conductometry).

Appropriate GIS software was used to analyse and process aerial photographs. Linearised regression models were applied to analyse relationships between reed morphometric parameters and soil properties. Values of the depended variables only were log10 transformed.

\section{Results}

The reed shoot height was found to range from 16 to 370 $\mathrm{cm}$, the stem diameter varying within $0.1-0.8 \mathrm{~cm}$. The soil moisture, organic matter content, $\mathrm{pH}$, and salinity ranges recorded were $66.1-85.4 \% ; 26.0-77.9 \% ; 5.3-6.9$; and $1.65-41.9 \mathrm{mS} \cdot \mathrm{cm}^{-1}$, respectively. The morphometric parameters of the common reed produced no significant correlations with soil moisture, $\mathrm{pH}$, and organic matter content. Relationships between the average shoot height, stem diameter, and soil salinity were exponential in nature. Semi-log models showed the average shoot height and stem diameter to be negatively affected by soil salinity ( $\mathrm{r}=-0.72$ and $\mathrm{r}=-0.52$, respectively) (Fig. 1).

The phototone variability and results of ground truthing are illustrated in Figure 2.

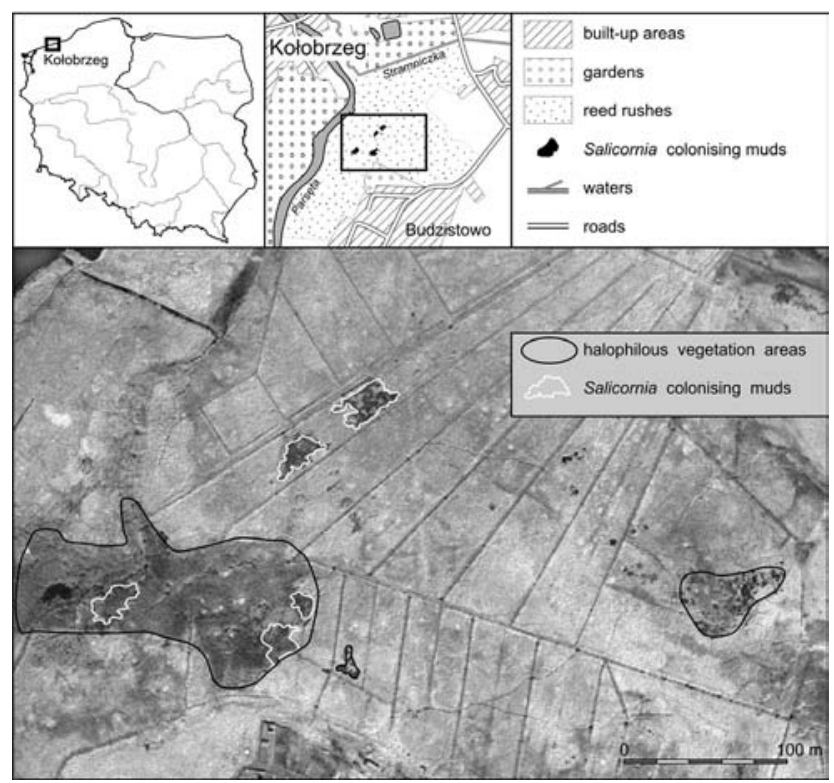

Figure 2. Distribution of halophilous vegetation patches determined from aerial photos and ground-truthed

Figure 1. Scatterplots in linearised regression models: average shoot height $(\log 10) \mathrm{vs} \mathrm{EC}_{\mathrm{e}}\left(\mathrm{r}^{2}=0.51\right)$ and average stem diameter $(\log 10)$ vs. $\mathrm{EC}_{\mathrm{e}}\left(\mathrm{r}^{2}=0.29\right) ; \mathrm{p}<0.001$
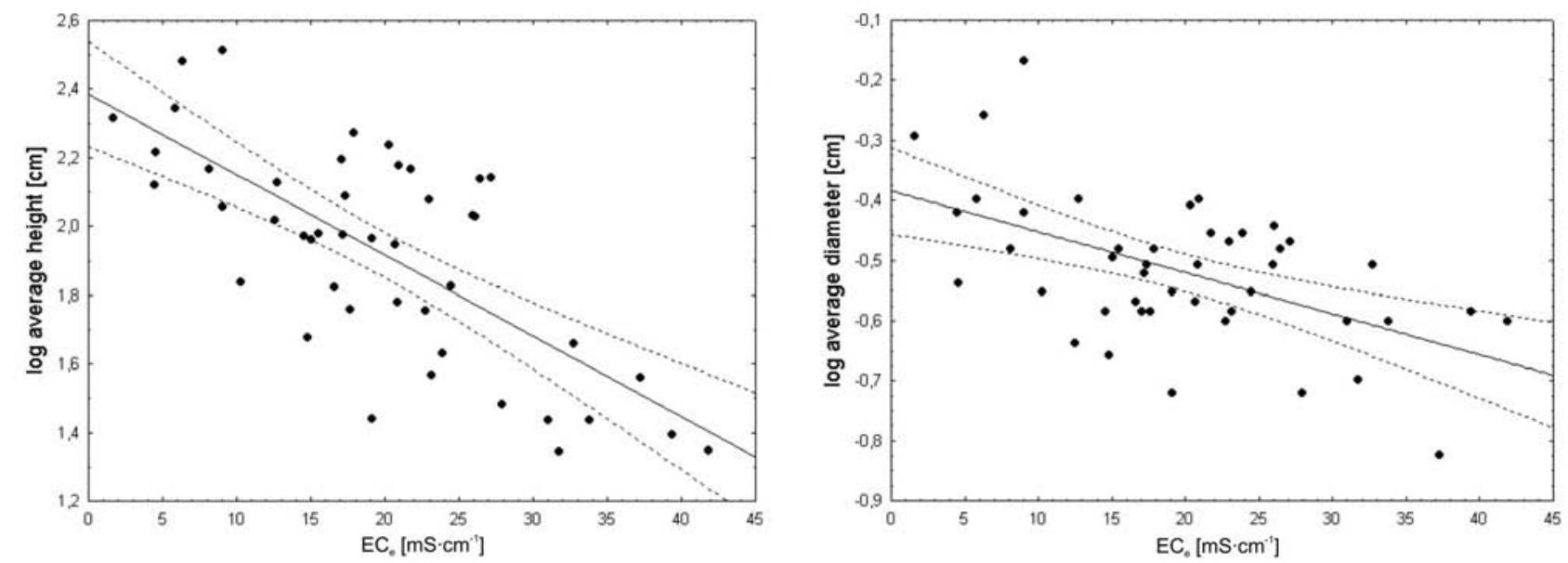


\section{Discussion}

Under brackish conditions, Phragmites australis will expand if successional processes are not restrained. The grass adapts to saline condition by adjusting the level of osmotically active solutes in its leaves. Maximum salinity levels tolerated by the common reed vary between 5-65\%. Increased salinity levels reduce many aspects of productivity in $P$. australis, including number of leaves, shoot height, and stem diameter; the amount of salt absorbed by the reeds is directly related to salinity of the location (Asaeda et al. 2003 and references therein). Reduction in shoot height and density of salt-stressed reed plant cover can be used to locate patches of halophilous vegetation scattered across vast and hardly accessible complexes of rushes.

\section{References}

Asaeda T., Manatunge J., Fujino T. \& Sovira D., 2003, Effects of salinity and cutting on the development of Phragmites australis, Wetland Ecology and Management 11: 127-140.

Bosiacka B., Podlasiński M. \& Pieńkowski P., 2011, Salt marshes determined by ascending brine in northern Poland: land-use changes and vegetation-environment relations - Phytocoenologia (in press).

Kaczor D., 2005, Zasolenie wód podziemnych kenozoiku Polski północno-zachodniej w wyniku ascenzji solanek z mezozoiku [Salinization of Cenozoic aquifers in NW Poland by ascending Mesozoic brines], Przegl. Geolog. 53 (6): 489-498. 